\title{
THE ISSUE OF PRICING POLICY IN OIL AND GAS SECTOR: WHY OIL PRICES RISING
}

\author{
Irina V. Onyusheva \\ Turan University, Almaty, Kazakhstan \\ Phyu Phyu Khaing \\ Stamford International University, Bangkok, Thailand \\ Noe Noe Aung \\ Strategy First Institute, Yangon, Myanmar
}

The given article is devoted to the current issue of pricing policy in oil and gas sector. Particularly, it has been studied the factors, causes and consequences of oil prices rising. The research methodology of this paper is based on conducting the comparative analysis of existing patterns of macroeconomic development, political differences and social issues within global oil and gas industry providers. The given analysis is based on SWOT, PESTEL, cause and effect modeling, risk management techniques, as well as the five forces model by M. Porter detecting competitive advantages of the related countries. It is also implemented the systematic vision and expert assessment. Moreover, it has been considered the possible solutions and recommendations on how to improve the current global economic situation.

Keywords: oil and gas, price, pricing policy, Brent, WTI, Dubai

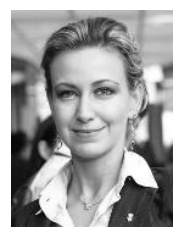

Irina Onyusheva

Dr., Prof., Turan University, Almaty, Kazakhstan

Interests - Economics, Strategic Management, Formation, ensuring and increasing economic competitiveness on both micro- and macro- levels; Human Capital development; HR Management; Knowledge Economy; Knowledge Management; Project Management; Management in Education

E-mail: dr.irina.onyusheva@gmail.com

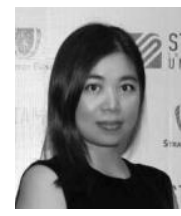

Phyu Phyu Khaing

Stamford International University, Bangkok, Thailand; Strategy First Institute, Yangon, Myanmar, International MBA Program

Interests - International Business Management, Strategic Management, HR Management

E-mail: phyu_phyu_khaing@gmail.com

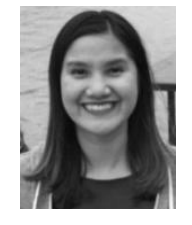

Noe Noe Aung

Stamford International University, Bangkok, Thailand; Strategy First Institute, Yangon, Myanmar, International MBA Program

Interests - International Business Management, Strategic Management, HR Management

E-mail: noe_noe_aung@gmail.com 


\section{Introduction}

In this paper, it is considered the current issue of pricing policy in the oil and gas sector. It is studied the factors which drive up the crude oil price and the possible causes and consequences of the oil business. The oil price is reaching $\$ 80$ per barrel and it has risen almost double in the past year according to the international benchmark. The rise of crude oil price caused the diesel and petrol cost also high and that may become the biggest challenges for many countries, which are already in above-target inflation.

Barclays bank predicted that the average oil price for this might be from $\$ 62$ to $\$ 73$ per barrel and some banks predicted that oil could knockout $\$ 100$ per barrel in the coming year (The Guardian, 2018).

The following are the reason crude oil prices are rising:

(1) Saudi Arabia has been negotiated with other OPEC countries and other main oil suppliers to raise the Brent crude price up into the $\$ 80$ per barrel to fund its social state and gets the progress on its state oil company Saudi Aramco. It was assuming that if the price between Brent and WTI stayed consistent, the WTI price would be still around \$75 per barrel (Forbes, 2018).

(2) On April 12, the International Energy Agency (IEA) declared that crude oil inventories will decrease in coming 2 to 3 months below the average last 5 years' production and it would be the effect on global supply and demand. Inventories of oil have been dropped 1 million barrels under in average five-year worldwide.

(3) One of the main reasons is OPEC who wishes the oil price to above $\$ 100$ per barrel for the estimative future. The Organization of Petroleum Exporting Countries (OPEC), the $40 \%$ of world oil supplier, is one of the main instabilities influencer in oil fields which consists of 14 countries: Saudi Arabia, the United Arab Emirates, Qatar, Iran, Iraq, Algeria, Angola, Ecuador, Equatorial Guinea, Gabon, Kuwait, Libya, Nigeria and Venezuela. This group plays the global oil and gas price by arranging the production levels to increase or decrease with global demand. However, OPEC produces a lot of oil production to turn down the price of $\$ 100$ to $\$ 50$ a barrel in mid-2014 for controlling the oil business(Forbes, 2018).

(4) Although the Middle East controls the oil price to cheap, oil production in Canada is more overpriced. The United States oil production also affects the rising oil price whereas the United States has an average output of 9 million barrels per day. The strike of Hurricane Katrina at the southern part of the United States in 2005 and the flooding of the Mississippi River in May 2011 affected the demands of the United States and fluctuate the price of oil. The unstable production in the United States pushes the risen oil prices as a result.

(5) Another strongest reason for raised the crude oil price is the US sanctions on Iran and Venezuela. Iran supplies around 4 percent of the total world's oil market and after President Trump elected in the United States, U.S declared that they would extract from the 2015 Iran nuclear arms agreement and refurbish sanctions on Iran. Venezuela is also facing a disputed presidential election, curbing on financing or logistics problem and constricting sanctions of the United States on Venezuela and those things will almost certainly cause the worse condition to Venezuela and it decreases the country's crude production (NDTV, 2018).

(6) Higher interest rates support the dollar stronger and which may affect currencies of other countries. At that time, most of the American oil companies buy more oil than the time whereas dollar is low against foreign currencies. 


\section{THE ISSUE OF PRICING POLICY IN OIL AND GAS}

All of these above factors with economic and political which can cause fluctuations in oil prices. We can see as OPEC as the main powerful actor of oil price fluctuations and other factors such as world oil supply and demand, the costs of oil production, political chaos and interest rates and strength of U.S dollar are the reasons of oil price rising.

Saudi Arabia is already arranging to substitute the dropping supplies from Iran, Libya, and Venezuela by extensively increasing the oil production and level of storage while Russia is also speeding up of oil exports. However, there is still uncertainty to fill the global oil demands and the production rate of OPEC and how long they can support. Riyadh, the city of Saudi Arabia aims two million barrels per day for extra production capacity, but they can only one million barrels of its daily output and there are no further barrels in reality production(The New York Times, 2018).

Transportation is the essential part of the logistics while goods are shipping from place to place that uses fuel is a key involvement such as the air transport, motor transport, water transport, etc. As the micro level economy, the risen of oil prices means the more cost of doing business process (Federal Reserve Bank of San Francisco, 2007).

The risings of oil price are commonly assumed to raise inflation and slow the progress of economic. Oil prices raised or inflation direct or indirect effect on the cost of goods sold related to petroleum products or transportation and production. "High oil prices also can reduce demand for other goods because they reduce wealth, as well as induce uncertainty about the future (Sill, 2007). "On the macroeconomy, costly productions also effect on a variety of products and services that production costs effect to consumers finally" (Federal Reserve Bank of San Francisco, 2007).

\section{Analytical Part}

To analyze the oil and gas industry based on the current issue, we use the two analytical parts: PESTEL and Porter's Five Forces. We aim to know that the factors of the external environment of the market and evaluate opportunities and threads for the oil and gas industry.

\section{PESTEL Analysis}

Saudi Arabia and Iran are now competing with each other in the oil pricing policies and the competition is a rather intense day by day. They are trying to get the market share as much as they can to be ahead of the price war of the US intention on Iranian oil.

Political and Legal Factors. Current price increases in oil and gas affects many countries and it will reflect the stability of the market. The main concerns or common causes that influence the decisions for oil and gas industry are geographic and political conflicts between countries and the stability of the countries' policies. The majority of the governments of the oil producing countries through their National Oil Companies control more than $90 \%$ of the proven oil reserves and over $75 \%$ of global oil and gas production (Greek Energy Forum, 2016).

OPEC consists of the countries, Iran, Iraq, Kuwait, Saudi Arabia, Venezuela, Qatar, Indonesia, Libya, United Arab Emirates, Algeria, Nigeria, Ecuador, Angola, and Gabon. As these countries have their own intentions and visions about political and economic issues, everything that happens within these countries will definitely affect the oil and gas prices, not to mention the taxes policies of these countries. 
Meanwhile in other countries, for instance, the U.S. hasn't been able to persuade China which is the largest customer of Iran's oil to lower the oil purchase, however, it is reported that Beijing has already limited the import of Iran's oil to the country. Moreover, other countries such as South Korea and Japan are now thinking not to proceed to buy Iran's oil and trying to find the other options. These factors make Iran very difficult to persuade those countries to continue buying its oil although it is trying to give discounts for Asian customers (Paraskova, 2018).

Considering the intensity of efforts by the U.S. to cut off as much Iranian oil exports as possible, it is unlikely that even Iran's significant discounts to Asian customers will save the country's oil exports. Analysts, and reportedly the U.S. Administration itself, currently expect the sanctions to remove around 1 million bpd from the oil market. Sanctions of the U.S on the Iranian oil cause major issue. For instance, as mention in Asia, although China is still buying Iranian oil, South Korea has stopped buying both crude and condensate since late June this year and that will cause the impact for oil market (Julian Lee, 2018).

Economic Factors. Saudi Arabia's economy is very much relying on the oil sector. Income created from oil will eventually go to Government revenue. The obvious fact is that the relationship between the global economy and the consumption of the oil and gas can impact on the matter. Furthermore, the oil and gas prices are the major factor, which shows or decides whether a country's reserve is economically feasible or not. In fact, unconventional and offshore oil and gas fields have the highest costs of extraction among the reserves (Greek Energy Forum, 2016).

"Higher oil prices will only help reduce the deficit and build reserves", Mohammed bin Abdullah Al-Jadaan of Saudi Arabia told CNBC's Hadley Gamble recently. "We have had a very successful year over the last year a lot has been achieved in terms of fiscal discipline, the government has been really very efficient in its spending and, overall, non-oil revenue has been as planned or even in certain parts (of the economy) better than planned," he said. He even said that oil revenues are increasing as prices rise, which are helping the country to reduce its deficit, which the government has managed "to reduce by 40 percent in the last two years" (Ellyatt, 2018).

Furthermore, the recent trade war between two of the biggest economy of the world; the USA and China have the effect on this matter. Trump has even proposed 25 percent tariffs on steel and 25 percent tariffs on aluminum. "Oil prices have fallen each time that the trade war escalates, with one key consequence of a trade war being a fall in oil demand as U.S. exports to the world's largest oil consumer fall. While the Iran wild card may threaten to push oil prices up - a trade war between China and the U.S. would have the opposite effect" (Rizvi, 2018).

Social Factors. Oil and energy sector's impact on social and economic of countries are basically connected as the economic situation of a country has the major impact on the society of that country. Main impacts could be the followings:

(1) Countries' consumption may reduce because of increasing oil prices.

(2) Vehicle transportation cost which is the affected by the increase in oil prices may cause the rise in traded goods prices as well. Thus, trade volumes will decrease and for the society, this would only mean losing sources of income, means might not be able to buy even essential food products. 


\section{THE ISSUE OF PRICING POLICY IN OIL AND GAS}

(3) Therefore, expenditure for food supplies (increasing food import costs) or social spending (increasing unemployment rate) would compete with the necessary investments in oil substitutes and green technology (Clarke, 2011).

Technological Factors. The role of the oil and gas companies such as Saudi Aramco is very important to invest in innovation and to be more effective and efficient in the oil sector. There should be more advanced technology created by the powerful market leaders in the industry. Many factors such as the cost, funding, skill, uncertainty over the prices, policies, rules and regulations are the factors, which have the impact on the players in the oil and gas market. Despite the increase of oil prices at the global level, many organizations are also now trying to produce or develop machines and vehicles that consume less fuel and oil as well as the alternatives or substitutions. That would be one of the solutions for reducing negative impacts of the oil price increases.

Environmental Factors. The global environmental issue can also affect the oil and gas industry. The recent global environmental trends for decreasing Carbon Di Oxide emissions which is to reduce the use of fossil fuels in the global energy mix and to increase the renewable sources of energy in the global energy mix can shape up the whole global oil and gas industry and can affect the prices of the oil. Many players in the markets are planning to invest in the renewable energy sector at the moment (Saudi Aramco SWOT \& PESTEL Analysis, 2018). Other than the recent causes of the oil prices, possible natural disaster should affect the prices of the resources. When there was a hurricane in south Texas with rain previous year, creating a significant dislocation in the U.S. oil market, which caused crude to rise nearly $3 \%$ in its wake (Dilallo, 2018).

\section{Porter's Five Forces}

In the oil industry, the competition is every day and on the other hand, today's oil prices are unbelievable rising. Despite Saudi Arabia promised production more, it may not be enough to offset declines in Iran, Libya, and Venezuela. In this situation, the firm needs the insight about the industry and current market situation. Hence, we want to analyze the industry based on the current issue by Porter's Five Forces. Porter's Five Forces framework is the effective strategic tool to analyze potentially profitable and risks or threats to the oil industry. The five forces are:

1. The threat of New Entrants

2. Power of Buyers

3. Power of Suppliers

4. Industry Rivalry

5. Threat of Substitutes

\section{The threat of New Entrants - Weak}

The oil industry is required a large amount of capital to establish a petroleum company. Firstly, it costs billions of dollars to develop oil fields for the easily accessible and offshore oil reserves to extract oil with the very advanced technologies. The equipment costs are very expensive and the skilled manpower cost is also high demand.

Secondly, it is not easy to get distribution channel in the petroleum industry because the oil companies operate at national or international well-own organizing distribution channel. In third, the important sector is government policies and legalization for the new 
entrants. The government used to favor to national oil companies because the resources for oil and gas are from the country and owned by the nations.

Thus, the threat of new entrants is weak for those reasons and also switching companies cost are high.

\section{Power of Buyers - Strong}

The industry cannot stand without potential buyers and buyers have a strong influence on the industry's profitability. Buyer is not end-users because of buyers are refiners, traders, distribution companies, national oil companies, and countries such as China, Japan, US, etc. (Mosa Zaidi, p. 3).

As buyers set up tenders and the government buy a large fleet with the global oil price, this leads buyers to seek the best contract terms. In addition, buyers can choose the suitable firm for a long-term business relationship and they evaluate negotiations in detail with more than one decision makers. Most of the buyers are from the developing countries due to the drivers' increase and high oil demand (Michael Porter's five forces: Oil industry, 2015). The oil industry is going to grow in the future despite the oil prices rising at present.

Buyers are interested in the prices and the quality of a product. It is known that global oil benchmarks play an important role in prices of crude oil. The main oil benchmarks are (1) Brent Blend (2) West Texas Intermediate (WTI) (3) Dubai/Oman (Fig. 1).

Today's oil price rising is not affected by the buyers because of buyers has bargaining power on how much consume amounts extensively such as EU, China, USA, Japan, and India in comparison with other countries (Athanasios Pitatzis, Porter's Five Forces Model for Oil and Gas Industry, 2016).

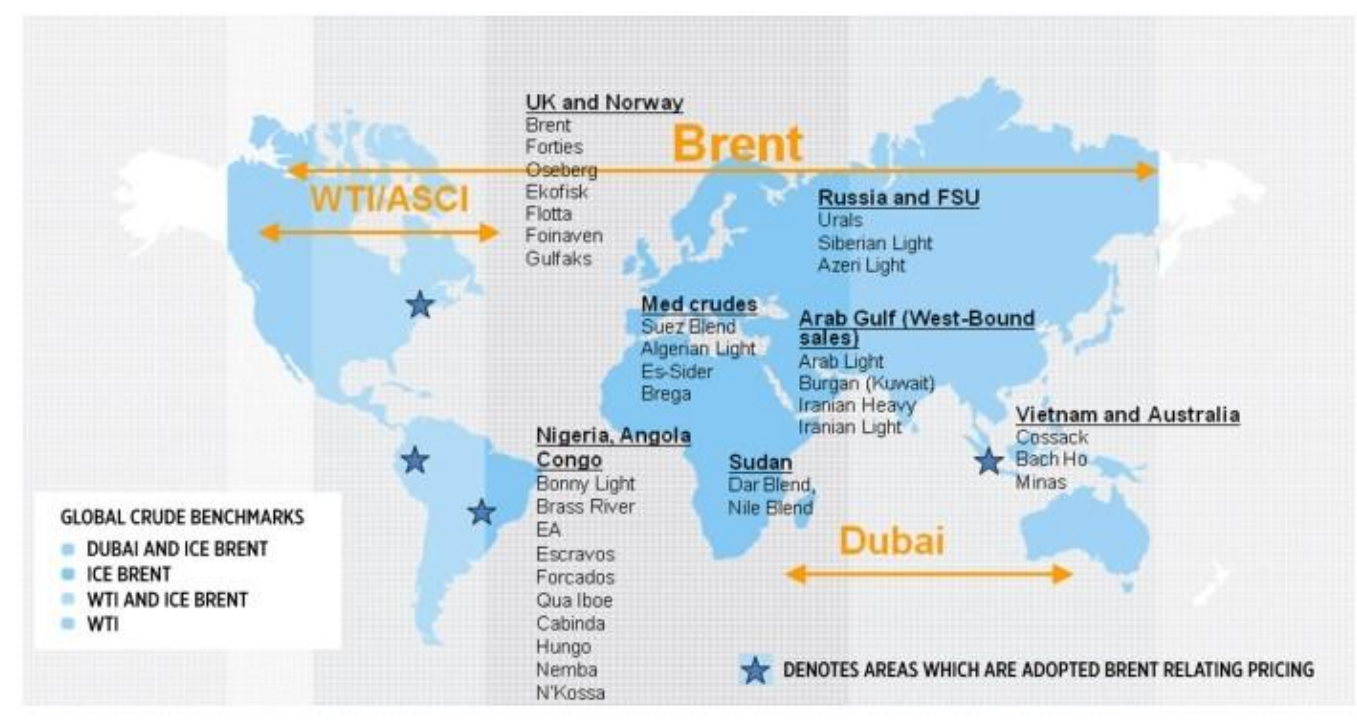

Figure 1 - Benchmark Oils: Brent Blend, WTI and Dubai (Source: energyroutes.eu)

\section{Power of Suppliers - Strong}

There are large numbers of suppliers and the strong equipment suppliers have more power. There is a complex suppliers network that supplier of equipment, materials, 


\section{THE ISSUE OF PRICING POLICY IN OIL AND GAS}

technicians, skilled manpower, and pipeline installation. The suppliers may eat into the industry by increasing the price or decreasing the quality. When the demand for oil is high, the supplier power is strong by a country and a long standing in the industry. There will be highly cost if switching to another product and the product is strongly important to buyers. The supplying oil industry has more profitability than the buying industry (UK Essays, 2015).

Some big suppliers are fully integrated into the oil and gas industry such as Chevron, Shell and National oil companies like Saudi Aramco, Gazprom, and Petrobras. On the other hand, some suppliers are the oil-rich countries. As their business segments involved in the oil and gas industry, their bargaining power is higher than buyers (Athanasios Pitatzis, Porter's Five Forces Model for Oil and Gas Industry, 2016).

The members of the Organization of the Petroleum Exporting Countries (OPEC) are nationalized oil productions in the countries. OPEC nations also have bargaining power because they hold $2 / 3(70 \%)$ of the whole world's oil reserves. Not only bargaining powers at OPEC countries but also they can manage the other firm to leave in the industry. At present, President Trump put has pressured Saudi Arabia to increase oil production by 2 million barrels per day if possible (Stanley Reed and Mihir Zaveri, 2018). Hence, the OPEC and Russia consider increasing oil production by around $1 \%$ of the global oil supply. Since suppliers power is strong and on the other hand, Nigeria's suppliers are cooperating to strike by workers and alternative issues due to the crude export dependency on the United States. Because of its threats to production in Iran, Libya, and Venezuela (Stanley Reed, 2018).

\section{Industry Rivalry - Very Strong}

Since the oil industry is very large and already matured, a firm stays for the lifetime and takes a strong position. A strong firm with a big market share and more power, and lower firm with a low market share and less power (Mosa Zaidi, p. 5). There are high exit barriers due to the huge capital assets. Bidding is very competitive to get contracts/agreement, but offer the lowest cost wins the bid.

\section{The threat of Substitutes - Weak}

There are many alternatives to oil such as coal, solar, wind power, natural gas, and nuclear energy. These alternatives resources could be replaced by a high amount of hydrocarbons used in the global energy mix with allow of their performance, quality, and price. For this strategy, needed a big amount to invest in R\&D and producing process. So, the possibility for substitutes powerful of the global energy mix until 2040 is very small (Athanasios Pitatzis, Porter's Five Forces Model for Oil and Gas Industry, 2016). Moreover, coal is already well known in the global market and natural gas will be high growth to compare to oil according to the analyst forecasted. Gas will have place market share for the residential, industrial and commercial use. Thus, substitute makes a big threat to oil production companies (Mosa Zaidi, p. 4).

In addition, the oil and gas industry is huge in the world. It must be well established to get the oil and gas from under the ground to the consumer with the specific technologies and different businesses. But this huge industry might be broken if lack of three linear each with its own set of challenges and opportunities that Upstream, Midstream, and Downstream (Oil $\&$ Gas). The chronological sectors of the oil and gas industry are presented in Fig. 2. 


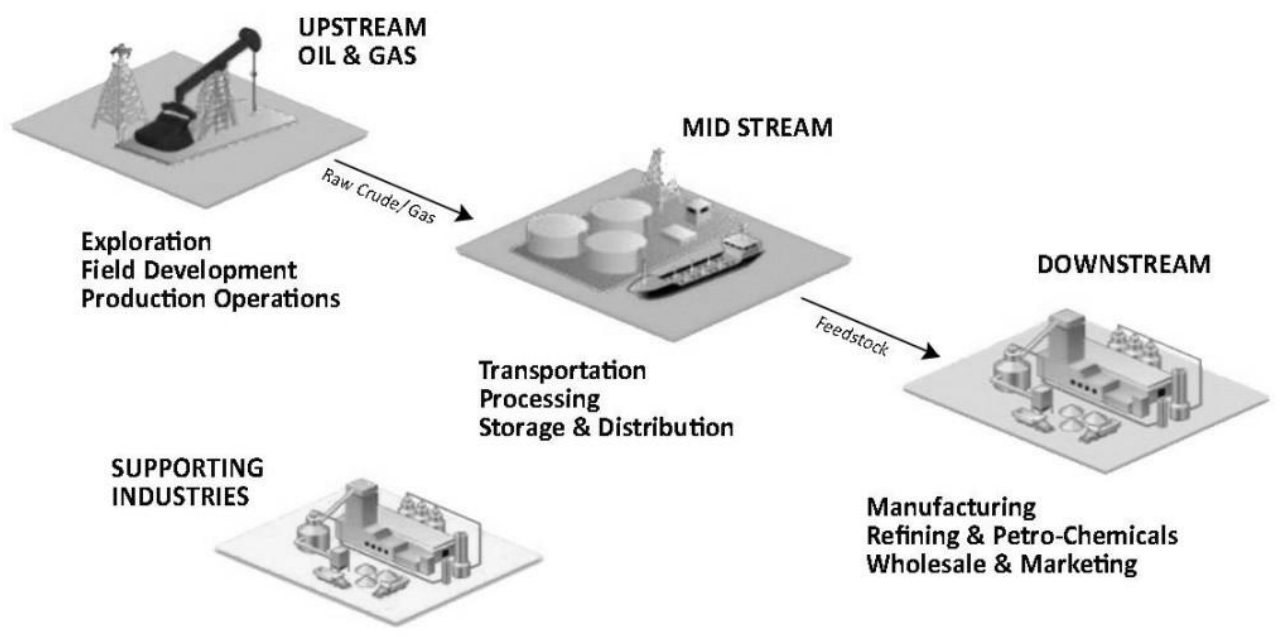

Figure 2 - Chronological Sectors of the Oil and Gas Industry

(Source: avata.com)

\section{Solutions \& Recommendations}

The crude oil price has been getting higher since 2014 and now reaches out to its highest in recent days. With the US sanctions over Iran with the case of nuclear relating dealing issues between Trump administration and Iran government. Consequently, the oil price reached out to more than $\$ 80$ a barrel, which was the highest during the four years and the lowest price was $\$ 29$ per barrel in early 2016. In addition, European energy companies will be no longer getting the benefits of special preferences in doing the business with the companies from Iran (Constable, 2018).

Oil prices in the US have been raised with the supply shortage from Libya, Venezuela and the last country is Iran with the sanctions issues. As the US is the huge importer of oil, it could impact a lot in oil prices for both companies and consumers. As a solution, the US government has a big hope for OPEC countries (Organization of the Petroleum Exporting Countries) and Russia could fill up the gap of the shortage that came from those three countries. On the other hand, Japan, India, and South Korea will stop the importing of Iranian oil if the US sanctions are confirm (Resnick-Ault, 2018).

There could be several ways that maintain the stable crude oil prices: the increased production of shale oil with alternative fuels in the US so that others region could share the imported volumes to the US, OPEC countries and Russia could increase the output, keep the stable foreign exchange currency rate and the last factor is that the decline in the global demand although this factor is unsure and unpredictable (AMADEO, 2018).

The U.S Energy Information Administration (EIA) forecasts that the fuel production in the US could reach to 10.8 million $\mathrm{b} / \mathrm{d}$ at the end of 2018 and it is also the highest yearly production in the history of the US. In 2017, they had produced 9.4 million b/d and could beat the record of this in 2018. The EIA estimates the oil production will increase up to 11.8 million b/d by next year, 2019 and the US production could jump to 12 million b/d by the end of 2019. The International Energy Administration expects that in the year of 2023, the United States will become the world's largest oil producers and they could meet the domestic demand of 30 million b/d per year consumption. The US government should encourage those 


\section{THE ISSUE OF PRICING POLICY IN OIL AND GAS}

sectors so that they could reduce relying on OPEC countries especially Saudi Arabia which was the main supplier of crude oil (AMADEO, 2018).

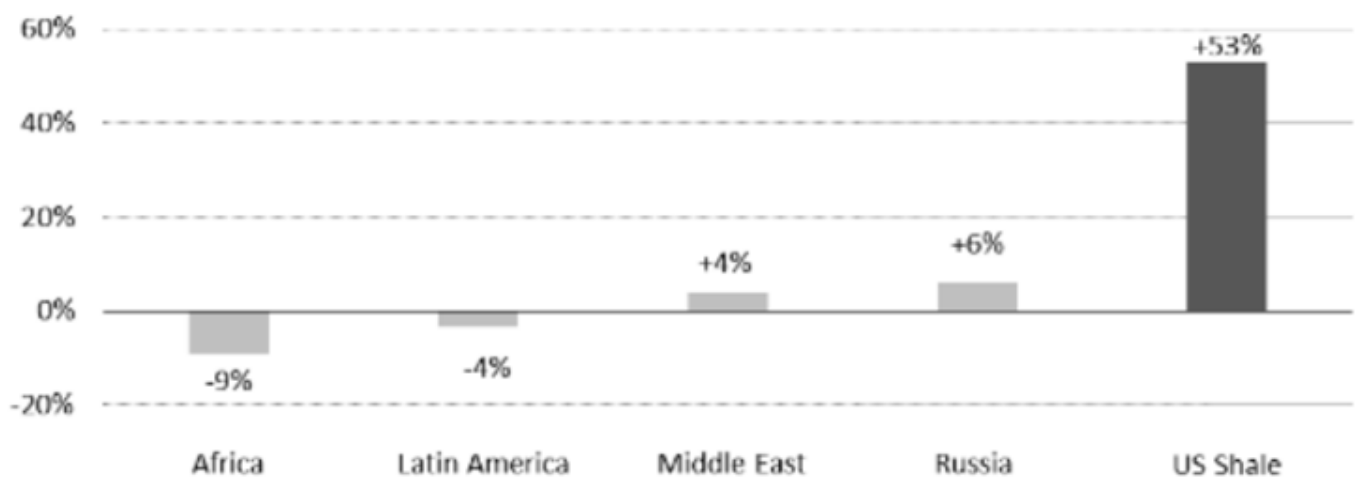

Figure 3 - Change in Upstream Investment, 2016-2017

(Source: Compiled on the base of data of oilprice.com)

The US shale industry is growing and more efficient as the investors will more focus on investing it and the IEA believes that $53 \%$ of the investment will come out exclusively form shale industry. With the increase in those numbers, OPEC countries are starting worrying that they could lose the demand from the US, which was quite huge if the shale industry were going well (Consultants, 2017).

OPEC has the new member in the second quarter of 2018, the Congo Republic and increased its output, increased by $320,000 \mathrm{bpd}$ from June to 32.64 million bpd in July, which was the highest production output for this year, 2018. Iran has a huge dropped in production by 100,000 bpd, which was the impact of US sanction. Unlikely, Saudi Arabia, Kuwait, and UAE have uplifted their production to follow the OPEC decision of boosting up the outputs. So that could cover the drop from other OPEC member countries that have the issues with sanctions such as Venezuela, Angola, and Libya (Paraskova, OPEC Oil Production Hits 2018 High In July, 2018).

Maintain the inflation rate and currency exchange rate is one of the options to control the oil price to be stable within the country as all the oil transactions are paid in US dollar. For petroleum exporting countries, the dollar exchange rate is one the main factors to be considered as it could impact the benefits and having the strong currency that aligned with the US dollar could help up to 70 percent of petroleum price (AMADEO, 2018).

In Myanmar, one of the major points that fuel price is getting higher since 2017 was coming from exchange rates, said by MPTA (Myanmar Petroleum Trade Association). During the August of 2017, currency exchange rate between Myanmar Kyats and US dollar was 1,361 MMK for 1 USD and the fuel prices per liter were (92 Ron) $680 \mathrm{MMK}$, gasoline (95 Ron) 715 MMK, diesel (10 ppm) 690 MMK and diesel (500 ppm) 670 MMK (AUNG, 2017). According to (Central Bank of Myanmar, 2018), the exchange rate on $18^{\text {th }}$ of August was 1,498 MMK versus with 1 dollar and the petroleum price was 970 MMK (Diesel 500 ppm), 985 MMK (Premium Diesel), 950 MMK (Octane 92) and 1,010 MMK for Octane 95 (Max Energy, 2018).

As the Myanmar currency is not strong enough compared with the USD dollar, there is a huge impact on our country in terms of fuel price is increasing. More than that, Myanmar 
has the policies of storage the petroleum, which means that local petroleum stations have the prescribed limit and they are not allowed to store a lot. To be distributed in the market, the Thilawa Port stores some 12,000 tons of fuel oil and it's quite difficult to handle the oil price and storage a lot in the stations because of the policy (Wai, 2018).

Finally, the last point is that China's oil consumption is going down and reaches out to their minimum level since December 2017(Alternative Fuel, 2018). The global demand for oil consumption was increased due to the demand came from China but the economic reforms growth rate of China was not as expected and impacted the global demand to be slow down. Another possible solution is that we could rely more on natural gas which is ecofriendly such as ethanol, biodiesel, natural gas, solar power, electric and others.

\section{References:}

The Guardian. (2018). What are the factors driving up the price of crude oil. Retrieved on 17.05.2018 from: https://www.theguardian.com/business/2018/may/17/what-are-the-factors-driving-upthe-price-of-crude-oil

Forbes. (2018). Five Reasons Why Oil Prices Could Move Even Higher. Retrieved on 16.04.2018 from https://www.forbes.com/sites/davidblackmon/2018/04/16/five-reasons-why-oil-pricescould-move-even-higher/

NDTV.com. (2018). Crude Oil Prices Soar To Highest Since 2014. 5 Reasons Why Crude Oil Prices Are Rising. Retrieved on 14.05.2014 from https://www.ndtv.com/business/crude-oil-pricessoar-to-highest-since-2014-5-reasons-why-crude-oil-prices-are-rising-1855671

The New York Times. (2018). Saudi Arabia Promised More Oil. So Why Are Prices Rising? Retrieved on 07.07.2018 from: https://www.nytimes.com/2018/07/04/business/energy-environment/oilprices-opec.html

Federal Reserve Bank of San Francisco. (2007). What are the possible causes and consequences of higher oil prices on the overall economy? Retrieved from: https://www.frbsf.org/education/publications/doctor-econ/2007/november/oil-prices-impacteconomy/

Mosa Zaidi. (2018). Retrieved on $\quad$ 16.08.2018, from https://www.academia.edu/26007879/Oil_and_Gas_industries_Analysis

UK Essays. (2015). Retrieved from https://www.ukessays.com/essays/management/analysis-ofmichael-porters-five-forces-management-essay.php

Athanasios, P. (2016). Energy Routes. Retrieved on 23.05.2016 from https://energyroutes.eu/2016/05/23/porters-five-forces-model-for-oil-and-gas-industry/

Stanley, R. \& Zaveri, M. (2018). The New York Times. Retrieved from https://www.nytimes.com/2018/06/30/us/trump-oil-saudi-arabia.html

Greek Energy Forum. (2016). Retrieved https://www.greekenergyforum.com/publications/studies/2016/pest-analysis-for-global-oil-andgas-companies-operations/

Rizvi, O. (2018). The six factors driving oil markets in 2018. Retrieved from https://oilprice.com/Energy/Crude-Oil/The-Six-Factors-Driving-Oil-Markets-In-2018.html

Clarke, D. (2011). Energy's Impact on Society- Part 1. Retrieved from https://oilprice.com/Energy/Energy-General/Energys-Impact-On-Society-Part-1.html

Dilallo, M. (2018). 10 factors affecting oil prices in 2018. Retrieved from https://www.fool.com/slideshow/10-factors-affecting-oil-prices-2018/?slide=10

Constable, S. (2018). Why Oil Prices Will Head Even Higher. Retrieved from: https://www.forbes.com/sites/simonconstable/2018/05/18/why-oil-prices-will-head-evenhigher/\#791c18e846aa 


\section{THE ISSUE OF PRICING POLICY IN OIL AND GAS}

Resnick-Ault, J. (2018). UPDATE 13-Oil gains on anticipation of sanctions on Iran. Retrieved from: https://www.cnbc.com/2018/06/29/reuters-america-update-13-oil-gains-on-anticipation-ofsanctions-on-iran.html

Paraskova, T. (2018). OPEC Oil Production Hits 2018 High In July. Retrieved from Oilprice.com: https://oilprice.com/Energy/Energy-General/OPEC-Oil-Production-Hits-2018-High-InJuly.html

Aung, H. L. (2017). Fuel prices on the rise. Retrieved from Myanmar Times: https://www.mmtimes.com/news/fuel-prices-rise.html

Central Bank of Myanmar. (2018). Retrieved from Reference Exchange Rate: http://forex.cbm.gov.mm/index.php/fxrate

Wai, K. H. (2018). Domestic consumers face mounting fuel oil price. Retrieved from: http://www.globalnewlightofmyanmar.com/domestic-consumers-face-mounting-fuel-oil-price/

Paper submitted

Paper accepted for publishing

Paper published online
21 July 2019

19 September 2019

30 November 2019 